\title{
PENGARUH MOTIVASI BELAJAR TERHADAP SIKAP RELIGIUS SISWA KELAS KHUSUS OLAHRAGA DI SMP NEGERI 1 KALASAN SLEMAN
}

\author{
Mudrik Asrori \\ Program Pasca Sarjana \\ Universitas Muhammadiyah Yogyakarta \\ E-mail: $\underline{\text { m.asrori0465@gmail.com }}$
}

\begin{abstract}
Abstrak
Penelitian ini bertujuan untuk mengetahui tingkat motivasi belajar siswa, untuk mengetahui sikap religius siswa dan untuk mengetahui pengaruh motivasi belajar terhadap sikap religius siswa. Metode penelitian ini menggunakan mixed methods dan penelitian ini bertempat di SMP Negeri 1 Kalasan. Waktu penelitian dilaksanakan bulan April-Juni 2018 dengan melibatkan 32 sampel kelas VIII, siswa Kelas Khusus Olahraga. Teknik pengumpulan data menggunakan angket, wawancara dan observasi. Analisis data kualitatif menggunakan reduksi data, display dan verifikasi data. Analisis data kuantitatif menggunakan regresi linear sederhana. Hasil dari penelitian ini 1) Motivasi belajar siswa termasuk kategori Tinggi $(77,97 \%)$ pada semua indikator. 2) Sikap religius siswa juga tergolong sangat tinggi (86,51\%). 3) Tingkat korelasi diperoleh data sebesar 0,702, artinya ada korelasi yang kuat antara motivasi belajar dan sikap spiritual. Hasil uji hipotesis diperoleh nilai thitung variabel motivasi belajar adalah sebesar 6,681. Sedangkan ttabel pada tingkat signifikansi 5\% (@=0,05). Hasil pengujian terdapat pengaruh yang signifikan dari motivasi belajar terhadap sikap religius.
\end{abstract}

Kata kunci: motivasi belajar, sikap religius, siswa SMP

\begin{abstract}
This study aims to determine the level of student learning motivation, to determine students 'religious attitudes and to determine the effect of learning motivation on students' religious attitudes. This research method uses mixed methods and this research is located at SMP Negeri 1 Kalasan. When the research was conducted in April-June 2018 involving 32 samples of class VIII, students of the Special Sports Class. Data collection techniques using questionnaires, interviews and observations. Qualitative data analysis using data reduction, display and data verification. Quantitative data analysis uses simple linear regression. Results of this study 1) Student learning motivation is in the High category (77.97\%) on all indicators. 2) The religious attitude of students is also classified as very high (86.51\%). 3) The correlation level obtained data of 0.702, meaning that there is a strong correlation between learning motivation and spiritual attitude. Hypothesis test results obtained tcount value of learning motivation is 6.681. While ttable at the 5\% significancelevel (@=0.05). The test results there is a significant influence of learning motivation on religious attitudes.
\end{abstract}

Keywords: learning motivation, religious attitude, junior high school students

\section{Info Artikel}

Diterima Agustus 2019, disetujui September 2019, diterbitkan Desember 2019 


\section{PENDAHULUAN}

Motivasi belajar siswa salah satunya dipengaruhi oleh kualitas pembelajaran di sekolah. Salah satu faktor yang mempengaruhi kualitas pembelajaran adalah penggunaan metode pembelajaran yang tepat dengan materi yang diajarkan. Dalam proses pembelajaran, guru harus menyadari betapa pentingnya pengetahuan dalam pemilihan dan penggunaan metode pembelajaran secara tepat, karena dengan penggunaan metode pembelajaran yang tepat akan membuat motivasi belajar siswa meningkat. Sikap religious akan muncul dengan adanya dampak dari motivasi yang baik. Dorongan untuk melakukan sebuah aktivitas yang potif dari dampak adanya pola keagamaan dari pengaruh motivasi yang kuat dari siswa.

Motivasi belajar menurut Hamzah B. Uno adalah dorongan internal dan eksternal pada siswa yang sedang belajar untuk mengadakan tingkah laku, pada umumnya dengan berupa indikator atau unsur-unsur yang mendukung. Indikator-indikator tersebut, antara lain adanya hasrat dan keinginan, dorongan dan kebutuhan dalam belajar, harapan dan cita-cita masa depan, penghargaan dalam belajar dan lingkungan belajar yang kondusif. Sikap merupakan tingkat afektif yang positif atau negatif yang berhubungan dengan objek psikologis. Hal senada juga disampaikan oleh Thorstone bahwa sikap merupakan tingkatan afeksi yang positif dan negatif yang dihubungkan dengan objek psikologi. Hal ini berarti sikap dapat dipelajari dan dapat berubah-ubah. Sikap adalah proses hasil belajar yang diperoleh melalui pengalaman, interaksi dan komunikasi yang terus menerus dengan lingkungan sekitarnya. Secara sadar atau tidak, individu memperhatikan objek yang ada di sekitarnya dan menentukan sikap terhadap objek tersebut.

Dalam pembetukan sikap, faktor pengalaman mempunyai peran yang sangat penting. Hal ini berarti sikap seseorang akan banyak dipengaruhi oleh lingkungan budaya misal-nya keluarga, norma, agama dan adat istiadat. Namun dalam pembetukan sikap seorang individu, faktor individu itu sendiri ikut menentukan. Dengan demikian, faktor internal dan eksternal sama-sama akan mempengaruhi terhadap pembentukan sikap dan perubahan diri seseorang. Sedangkan dalam Kamus Bahasa Indonesia, religi diartikan sama dengan agama yakni memuat aturan-aturan dan cara-cara mengabdi kepada Tuhan yang terkumpul dalam kitab suci yang harus dipahami dan mempunyai sifat mengikat kepada manusia, karena agama mengikat manusia dengan Tuhan.

Sementara itu, Nurcholish Madjid menyatakan bahwa religiusitas adalah tingkah laku yang sepenuhnya dibentuk oleh kepercayaannya kepada keghaiban atau alam ghaib, yaitu kenyataan-kenyataan yang supra empiris. Ia melakukan yang empiris sebagaimana layaknya, tetapi ia meletakkan nilai sesuatu yang empiris di bawah supra empiris. Menurut Jalaluddin mendefinisikan religiusitas merupakan suatu keadaan yang ada dalam diri seseorang yang mendorongnya untuk bertingkah laku sesuai dengan kadar ketaatannya terhadap agama. Religiusitas merupakan perilaku yang bersumber langsung atau tidak langsung kepada nash.

Dari penyataan di atas menunjukan bahwa pada prinsipnya sikap adalah kecenderungan individu terhadap suatu untuk bertindak dengan cara tertentu, apakah dalam bentuk menerima atau kecenderungan untuk menolak. Ketika mereka menerima, mereka cenderung menerima maka mereka menghayati serta mereka mencintai dan selalu ingin berbuat. Namun apabila mereka menolak maka muncul perbuatan membenci dan cenderung menghindari. Sebagai reaksi, maka sikap selalu berhubungan dengan dua hal, yaitu like and dislike, menurut dan melaksanakan atau menjauhi dan 
menghindari sesuatu. Dengan demikian sikap dapat pula bersifat positif ataupun bersifat negatif.

\section{METODE PENELITIAN}

Jenis penelitian yang dilakukan oleh penulis adalah lapangan (field research) peneliti menggunakan jenis penelitian campuran/kombinasi (mixed methodology). Mixed Method adalah penelitian yang melibatkan penggunaan dua metode, yaitu metode kuantitatif dan metode kualitatif dalam studi tunggal (satu penelitian). Penggunaan dua metode ini dipandang lebih memberikan pemahaman yang lebih lengkap tentang masalah penelitian daripada penggunaan salah satu di antaranya. Penelitian metode campuran merupakan pendekatan penelitian yang mengombinasikan atau mengasosiasikan bentuk kualitatif dan bentuk kuantitatif.

Tempat penelitian adalah SMP Negeri 1 Kalasan Kabupaten Sleman. Waktu penelitian adalah bulan April-Juni 2018. Subyek penelitian akan dilakukan secara purposive. Adapun yang menjadi subyek penelitian ini adalah siswa kelas VIII Khusus Kelas Olahraga (KKO) SMP Negeri Kalasan tahun pelajaran 2017/2018. Teknik pengumpulan data menggunakan angket, wawancara dan observasi. Untuk analisis data kualitatif menggunakan reduksi data, display dan verifikasi data atau kesimpulan, sedangkan analisis data kuantitatif menggunakan regresi linear sederhana.

\section{HASIL PENELITIAN DAN PEMBAHASAN Motivasi Belajar Siswa Daya Penggerak/dorongan}

Daya dorong dalam belajar akan menjadi penyemangat siswa dan memusatkan perhatiannya sehingga dalam merencanakan dan melaksanakan pembelajaran seorang guru diharapkan mampu menjembatani apa yang menjadi tujuan dari siswa tersebut. Daya dorong seorang siswa dalam penelitian ini meliputi ingin memperjuangkan citacita dan motivasi dari orang tua.

\section{Kegiatan Belajar}

Dalam keseluruhan proses pendidikan di sekolah, kegiatan belajar merupakan kegiatan yang paling pokok. Ini berarti berhasil tidaknya pencapaian tujuan pendidikan banyak tergantung kepada bagaimana proses kegiatan yang dialami oleh siswa sebagai anak didik. Indicator untuk mengetahui keberhasilan kegiatan pembelajaran meliputi antusias siswa dalam mengikuti pelajaran, mampu memahami pelajaran dengan baik dan senang bertanya apabila ada materi yang belum dipahami serta mengutamakan mengerjakan tugas.

\section{Unsur Pendukung}

Motivasi belajar dipengaruhi banyak faktor, selain dari diri siswa (instrinsik), juga dipengaruhi dari faktor luar (ekstrinsik). Dalam proses pembelajaran banyak sekali dipengaruhi oleh unsur-unsur pendukung yang tergabung dalam satu komponen. Semua komponen dalam sistem pengajaran saling berhubungan dan saling mempengaruhi untuk mencapai tujuan pengajaran. Pada dasarnya, proses pengajaran dapat terselenggara secara lancar, efisien, dan efektif berkat adanya interaksi yang positif, konstruktif, dan produktif antara berbagai komponen yang terkandung di dalam sistem pengajaran tersebut. Dalam penelitian ini faktor yang mempengaruhi motivasi belajar siswa adalah guru, lingkungan sekolah dan relasi dengan teman. 


\section{Arah dan Tujuan}

Dalam suatu kegiatan pasti memiliki suatu tujuan yang hendak dicapai, dan untuk mewujudkan tujuan tersebut memerlukan pengorbanan, usaha yang maksimal dengan segala kemampuan yang ada. Keberhasilan dari tujuan yang hendak dicapai dalam suatu kegiatan tergantung kepada kesungguh-sungguhan pelaku kegiatan dalam menjalankan kegiatan tersebut untuk mencapai tujuan yang dikehendaki. alam dunia pendidikan pun segala kegiatan yang dilakukan pasti mempunyai suatu tujuan yakni melakukan suatu perubahan-perubahan yang pasti kearah kemajuan, kearah perbaikan. Dalam penelitian, tujuan dari proses pembelajaran meliputi: menjadikan siswa menjadi disiplin, mendapatkan nilai yang bagus dan menjurai berbagai perlombaan.

\section{Perubahan Tingkah laku}

Indicator perubahan tingkah laku meliputi selalu berpikir tenang apabila mendapatkan masalah, senang mendapatkan masukan atau kritik dari orang lain dan belajar lebih tekun apabila mendapatkan nilai yang belum memuaskan.

Berdasarkan penjelasan di atas dapat disimpulkan bahwa tingkat motivasi belajar siswa termasuk kategori 'Tinggi' (77,97\%).

\section{Sikap Religius Siswa}

Sikap religius meliputi lima aspek yaitu aspek keyakinan, aspek ibadah, aspek pengalaman, aspek pengetahuan dan aspek pengamalan. Berdasarkan penjelasan di atas dapat disimpulkan bahwa sikap religious siswa SMP Negeri 1 Kalasan termasuk kategori 'Sangat Tinggi' (86,51\%). Sedangkan pengaruh motivasi belajar terhadap sikap religius siswa sebesar 0,702. Artinya terdapat pengaruh yang signifikan antara motivasi belajar dengan sikap religius.

\section{SIMPULAN DAN REKOMENDASI}

Dari hasil kajian yang telah dilakukan oleh peneliti, maka penelitian ini menyimpulkan sebagai berikut:

1. Motivasi belajar siswa di SMP Negeri 1 Kalasan termasuk kategori Tinggi $(77,97 \%)$ pada semua indikator. Terbukti dengan skor indicator motivasi belajar pada daya penggerak $(88,28)$, kegiatan belajar $(73,24)$, dukungan lingkungan $(80,47)$, arah dan tujuan $(81,51)$ serta perubahan tingkah laku $(71,35)$.

2. Sikap religius siswa SMP Negeri 1 Kalasan tergolong sangat tinggi (86,51\%). Hal ini dapat dilihat pada indicator sikap religious yang meliputi aspek keyakinan $(95,83)$, ritualistik $(89,06)$, pengalaman $(80,08)$, pengetahuan $(77,73)$ dan pengamalan $(89,06)$.

3. Terdapat pengaruh yang signifikan motivasi belajar terhadap sikap religius siswa sebesar 0,702 artinya ada korelasi yang kuat antara motivasi belajar dan sikap spiritual. Sedangkan hasil uji hipotesis diperoleh nilai thitung variabel motivasi belajar adalah sebesar 6,681. Sedangkan ttabel pada tingkat signifikansi 5\% (@ = $0,05)$ dan derajat bebas $=30(32-2)$ pada pengujian dua arah adalah sebesar 2,013. Karena nilai thitung $(6,681)$ lebih besar dari ttabel $(2,013)$, maka diputuskan untuk menolak Ho dan menerima $\mathrm{Ha}$, jadi hasil pengujian menyimpulkan terdapat pengaruh yang signifikan dari motivasi belajar terhadap sikap spiritual. 


\section{DAFTAR PUSTAKA}

Afifudin, Psikologi Pendidikan Anak Usia Sekolah Dasar, Solo: Penerbit Harapan Massa, 1986

Ali Abdul Halim Mahmud, Akhlak Mulia, penerjemah Abdul Hayyie al-Kattani, dkk, Jakarta: Gema Insani, 2004

Barker, Chris, et.al, Research Methods in Clinical Psychology, England: John Wiley \& Sons. Ltd., 2002

Creswell, John W., Research Design; Pendekatan Kualitatif, Kuantatif dan Mixed, Yogyakarta: Pustaka Pelajar, 2014

Elida Priyitno, Motivasi dalam Belajar, Jakarta: P2LPTK, 1989

Endang Sri Astuti dan Resminingsih, Bahan Dasar Untuk Pelayanan Konseling pada Satuan Pendidikan Menengah Jilid I, Jakarta: PT Grasindo, 2010

Hamzah B. Uno, Teori Motivasi dan Pengukurannya, Jakarta: Bumi Aksara, 2011

Jabrohim, Tahajut Cinta, Yogyakarta: Pustaka Pelajar, tt

Jalaluddin, Psikologi Agama, Jakarta: RajaGrafindo Persada, 2016

Muhibbin Syah, Psikologi Pendidikan dengan Pendekatan Baru, Bandung: Remaja Rosdakarya, 2002

Mulyadi Psikologi Pendidikan, Malang: Biro Ilmiah IAIN Sunan Ampel, 1991

Nurcholish Madjid, Islam, Doktrin dan Peradaban, Sebuah Telaah Kritis tentang Masalah Keimanan, Kemanusiaan dan Kemodernan, Jakarta: Yayasan Wakaf Paramadina, 1992

Pusat Pembinaan dan Pengembangan Bahasa Departemen Pendidikan dan Kebudayaan, Kamus Besar Bahasa Indonesia, Jakarta: Balai Pustaka, 2012

Ramayulis, Psikologi Agama, Jakarta: Kalam Mulia, 2013

Samidjo Mardiani, Bimbingan Belajar, Bandung: Armico, 1985

Sardiman AM., Interaksi dan Motivasi Belajar Mengajar, Jakarta: Rajawali Press, 2016

Sugiyono, Metode Penelitian Kombinasi (Mixed Methods), Bandung: Alfa Beta, 2012

Suharsimi Arikunto, Prosedur Penelitian Suatu Pendekatan Praktik, Jakarta, Rineka Cipta, 1995 
Tadjab, Ilmu Pendidikan, Surabaya: Karya Abditama, 1990

Winkel W.S., Psikologi Pengajaran, Jakarta: Gramedia, 2000 